\title{
ANALISIS PENGENDALIAN PERSEDIAAN BAHAN BAKU DENGAN MENUNJANG KEEFEKTIFITASAN PROSES PRODUKSI MEUBELAIR PADA PERUSAHAAN UD. JAYA ABADI PUTRA KEDUNGPRING LAMONGAN
}

\author{
Sandi Julianto \\ Fakultas Ekonomi universitas Islam Daru Ulum Lamongan \\ Email: sandijulianto1993@gmail.com
}

\begin{abstract}
This research to determine the policy of controlling raw material inventory in a company if it uses the Economic Order Quantity (EOQ) method with current company policy. The data used in the form of data about the main raw material needs and the costs incurred in ordering and storing during 2017-2019. Data collection techniques by examining company documents. The research method used is descriptive discussion that is to make a systematic picture using the object under study. The results of the analysis are known to control raw material inventory at UD. Jaya Abadi Putra Kedungpring Lamongan can be concluded as follows (1) The optimal number of raw material inventory purchases using the economic order quantity method in 2017 is 176.93 $m 3$ with a purchase frequency of 16 times, in 2018 amounting to $170.58 \mathrm{~m} 3$ with purchase frequency 16 times, in 2019 is $165.72 \mathrm{~m} 3$ with a purchase frequency of 16 times. And the total cost of raw material inventory of the company in the calculation of economic order quantity in 2017 is Rp. 962,606.69 in 2018 amounting to Rp. 1,063,484.4, in 2019 amounting to Rp. 1,112,250,3. (2). Safety stock / Safety Stock according to the results of the calculation of economic order quantity in 2017 is $29 \mathrm{m3}$, in 2018 is $24.33 \mathrm{m3}$, in 2019 is 19.84. Reorder points according to the calculation of economic order quantity in 2017 amounted to $57.14 \mathrm{m3}$, in 2018 amounted to $52.23 \mathrm{m3}$, in 2019 amounted to $46.96 \mathrm{m3}$.
\end{abstract}

Keywords: Inventory control. And the Economic Order Quantity Method

Abstraksi : Penelitian ini bertujuan mengetahui kebijakan pengendalian persediaan bahan baku pada perusahaan jika menggunakan metode Economic Order Quantity (EOQ) dengan kebijakan perusahaan saat ini. data yang digunakan berupa data tentang kebutuhan bahan baku utama dan biaya-biaya yang ditimbulkan dalam pemesanan dan penyimpanan selama tahun 2017-2019. Teknik pengumpulan data dengan cara pemeriksaan dokumen perusahaan. Metode penelitian yang digunakan adalah pembahasan deskriptif yaitu membuat gambaran secara sistematis menggunakan objek yang diteliti. Hasil analisis diketahui pengendalian persediaan bahan baku pada UD. Jaya Abadi Putra Kedungpring Lamongan dapat disimpulkan sebagai berikut (1) Jumlah pembelian persediaan bahan baku yang optimal dengan menggunakan metode economic order quantity pada tahun 2017 adalah sebesar 176,93 m3 dengan frekuensi pembelian 16 kali, pada tahun 2018 adalah sebesar 170,58 m3 dengan frekuensi pembelian 16 kali, pada tahun 2019 adalah sebesar 165,72 m3 dengan frekuensi pembelian 16 kali. Dan total biaya persediaan bahan baku perusahaan dalam perhitungan economic order quantity pada tahun 2017 sebesar Rp. 962.606,69 pada tahun 2018 sebesar Rp. 1.063.484,4, pada tahun 2019 sebesar Rp. 1.112.250,3. (2). Persediaan pengaman /Safety Stock menurut hasil perhitungan economic order quantity pada tahun 2017 adalah 29 m3, tahun 2018 adalah 24,33 m3, tahun 2019 adalah 19,84. Titik pemesanan kembali (Reorder Point) 
menurut perhitungan economic order quantity pada tahun 2017 sebesar 57,14 m3, tahun 2018 sebesar 52,23 m3,pada tahun 2019 sebesar 46,96 m3.

Kata kunci : Pengendalian persediaan. Dan Metode Economic order Quantity,

\section{PENDAHULUAN}

Perekonomian saat ini telah berkembang dengan pesat, seiring dengan pesatanya perkembangan llmu pengetahuan dan tekonologi yang semakin canggih. Sehingga persaingan antar pabrik menjadi semakin ketat. Adanya persaingan yang semakin ketat antar pabrik mendorong setiap pabrik untuk menetapkan pengendalian terhadap persediaan bahan baku secara tepat sehingga pabrik dapat tetap eksis untuk dapat mencapai tujuan yang diinginkannya.

Setiap pabrik baik itu pabrik jasa maupun pabrik hadycraft (kerajinan) pastilah mempunyai tujuan yang sama yaitu memperoleh laba atau keuntungan. Tetapi untuk mencapai tujuan tersebut tidaklah mudah karena hal itu dipengaruhi oleh beberapa faktor, dan pabrik harus mampu untuk menangani faktor-faktor tersebut. Masalah produk merupakan masalah yang sangat penting bagi pabrik karena hal tersebut sangat berpengaruh terhadap laba yang diperoleh pabrik. Apabila proses produksi berjalan dengan lancar maka tujuan pabrik dapat tercapai, tetapi apabila proses produksi tidak berjalan dengan lancar maka tujuan perusaan tidak akan tercapai. Sedangkan kelancaran proses produksi itu sendiri dipengaruhi oleh ada atau tidak ada bahan baku yang akan diolah dalam produk.

Kesalahan dalam penetapan investasi pada pabrik akan menekan keuntungan yang diperoleh pabrik. Adanya investasi yang terlaluh besar pada pabrik. Akan mempengaruhi jumlah biaya penyimpanan yaitu biayabiaya yang dibeli. Biaya ini berubahubah sesuai dengan besar kecilnya bahan yang disimpan. Semakin besar jumlah biaya yang disimpan maka semakin besar pula biaya penyimpanan. Biaya penyimpanan ini meliputi biaya pemeliharaan, biaya asuransi, biaya sewa gundang dan biaya yang terjadi sehubungan dengan kerusakan barang yang disimpan dalam gundang. Begitu juga sebaliknya jika investansi pada persediaan terlalu kecil maka juga dapat menekan keuntungan pabrik, hal ini disebabkan karena adanya biaya stockout yaitu biaya yang tejadi akibat pabrik kehabisan persediaan yang meliputi hilangnya kesempatan memperoleh keuntungan karena permintaan konsumen tidak dapat dilayani, proses produksi yang tidak efisien dan biaya-biaya yang terjadi akibat pembelian bahan secara serentak.

Untuk mencapai proses produksi yang efektif, maka hal-hal yang berkaitan dengan proses produksi harus diperhatikan, kemampuan yang dimilki oleh perusahaan harus dijalankan demi tercapainya Efektifitas produksi kemampuan ini dapat berupa sumber daya yang dimiliki oleh perusahaan, sumber daya yang dimiliki oleh perusahaan tersebut dapat digunakan untuk mencapai tujuan yang telah ditetapkan.

\section{TINJAUAN PUSKATA}

\section{Pengendalian Persediaan Bahan Baku}

Menurut Badrudin (2014: 216) pengendalian merupakan suatu aktifitas yang memungkinkan adanya intervensi positif dalam memeriksa arah yang diambil dan mengevaluasi hasil atau penyimpangan dari perencanaan sebelumnya, oleh karena itu pengendalian harus bersifat 
komprehensif dan terbuka terhadap berbagai hasil kinerja yang dilakukan.

Pengendalian merupakan usaha manajemen untuk mencapai tujuan yang telah ditetapakan dengan melakukan perbandingan secara terus-menerus antara pelaksanaan dengan rencana. Pengendalian berkisar pada kegiatan memberikan pengamatan, pemantauan, penyelidikan dan pengevaluasian keseluruh bagian manajemen agar tujuan yang ditetapkan dapat tercapai.

Menurut Stephanie Dian Hapsari, Bobby W. Saputra, Bambang Rismadi, Journal of Management Studies (2013 : 40) Pengendalian bahan baku merupakan penyediaan bahan baku dengan kuantitas dan kualitas yang telah ditetapkan dan dapat dipertanggung jawabkan secara penuh dan dipergunakan secara efisien. Pengendalian bahan baku meliputi perencanaan pembelian, penerimaan, persediaan, penggunaan, dan bahan sisa. Biaya bahan baku merupakan biaya yang besar maka penggunaannya secara efektif merupakan faktor penting dalam menetukan pencapaiantujuan perusahaan.

\section{Penggunaan Bahan Baku}

Menurut Mulyadi (2015: 275) bahan baku adalah merupakan bahan yang membentuk bagian menyeluruh produk jadi.Yang dimaksud dengan bahan baku dalam penelitian ini adalah bahan yang digunakan dalam produksi pada pabrik.Seluruh pabrik yang berproduksi untuk menghasilkan satu atau beberapa macam produk tentu akan selalu memerlukan bahan baku untuk pelaksanaan proses produksinya. Bahan baku merupakan input yang penting dalam berbagai produksi. Kekurangan bahan baku yang tersedia dapat berakibat terhentinnya proses produksi karena habisnya bahan baku untuk diproses. Akan tetapi terlalu besarnya bahan baku dapat mengakibatkan tingginya persediaan dalam pabrik yang dapat menimbulkan berbagai resiko maupun tingginya biaya yang dikeluarkan pabrik terhadap persediaan tersebut.

Untuk lebih dari memahami arti dari bahan baku, maka penulis akan mengemukakan beberapa pendapat mengenai pengertian dari bahan baku.

\section{Kebutuhan Bahan Baku}

Menurut Mulyadi (2015: 280)

Kebutuhan bahan baku merupakan Perencanaan kuantitas bahan baku yang dibutuhkan untuk keperluan produksi pada periode mendatang. Pada umumnya persediaan bahan baku yang diselenggarakan oleh suatu pabrik akan dipergunakan oleh suatu pabrik akan dipergunakan untuk menunjang pelaksanaan proses produksi yang bersangkutan tersebut. Dengan demikian maka besarnya persediaan bahan baku tersebut akan disesuaikan dengan kebutuhan bahan baku tersebut untuk pelaksanaan proses produksi yang ada didalam pabrik. Jadi untuk menentukan berapa banyak bahan baku yang akan dibeli oleh suatu pabrik pada suatu periode akan banyak tergantung kepada berapa besarnya kebutuhan pabrik tersebut akan masing-masing jenis bahan baku untuk keperluan proses produksi yang dilaksanakan dalam pabrik yang bersangkutan.

Untuk dapat mengetahui berapa besarnya kebutuhan bahan baku yang diperlukan pabrik pada suatu periode tersebut maka manajemen pabrik tentunya akan menggunakan data yang cukup relevan untuk mengadakan peramalan kebutuhan bahan baku dalam pabrik tersebut. Beberapa data yang dapat dipergunakan dalam penyusunan peramalan kebutuhan bahan baku ini antara lain adalah data dari perencanaan produksi yang akan dilaksanakan dalam pabrik yang bersangkutan tersebut. Disamping data tersebut, maka kadangkadang manajemen pabrik yang 
bersangkutan akan mempergunakan data penggunaan bahan baku dari beberapa periode yang telah lalu. Hal ini lebih sering digunakan oleh 25 pabrik-pabrik dimana proses produksi yang dilaksanakan adalah proses produksi terus-menerus sehingga pelaksanaan proses produksi dengan cara urutan dan non produk yang sama dari waktu ke waktu.

\section{METODE PENELITIAN Pendekatan Penelitian}

Penelitian ini menggunakan pendekatan penelitian kuantitatif. Menurut Soeyono dalam buku Pengantar Metodologi Penelitian karya Jusuf Soewadji (2012:50) penelitian kuantitatif merupakan jenis penelitian yang didasarkan atas perhitungan persentase, rata-rata, $\mathrm{Ci}$ kuadrat, dan perhitungan statistik lainnya.

Adapun jenis penelitian ini yaitu penelitian deskriptif. Menurut Jusuf Soewadji (2012:26) penelitian deskriptif adalah penelitian yang bertujuan untuk melukiskan secara sistematis fakta-fakta atau karakteristik populasi tertentu atau bidang tertentu, baik berupa keadaan, permasalahan, sikap, pendapat, kondisi, prosedur atau sistim secara faktual dan cermat.

\section{Populasi, Sampel dan Teknik Pengambilan Sampel}

Populasi

Populasi adalah wilayah generalisasi yang terdiri atas objek atau subjek yang mempunyai kualitas dan karakteristik tertentu yang ditetapkan oleh peneliti untuk dipelajari dan kemudian ditarik kesimpulannya (Sugiyono 2013:117). Populasi yang di pilih oleh peneliti adalah populasi persediaan dan penggunaan bahan baku di UD Jaya Abadi Putra

Sampel
Sampel adalah bagian dari jumlah dan karakteristik yang dimiliki oleh Populasi tersebut. Apabila peneliti melakukan penelitian terhadap populasi yang besar, seme ntara peneliti ingin meneliti tentang populasi tersebut dan peneliti memiliki keterbatasan dana, tenaga dan waktu, maka peneliti menggunakan teknik pengambilan sampel, sehingga generalisasi kepada populasi yang diteliti. Maknanya sampel yang diambil dapat mewakili atau representative bagi populasi tersebut dan sampel yang diambil oleh peneliti adalah persediaan dan penggunaan bahan baku di UD Jaya Abadi Putra tahun 2017-2019

\section{HASIL DAN PEMBAHASAN Analisis Data}

1. Perhitungan biaya pemesanan dan biaya penyimpanan.

a. Biaya pemesanan setiap kali pesan $(\mathrm{S})$

$$
\begin{aligned}
\text { 1) Tahun } 2017 \\
\begin{aligned}
\mathrm{S} & =\frac{\text { Total Biaya Pesan }}{\text { Frekuensi pemesanan }} \\
& =\frac{\text { Rp. } 750.000}{24 \mathrm{kali}} \\
& =\text { Rp. } 31.250
\end{aligned}
\end{aligned}
$$

2) Tahun 2018

$$
\begin{aligned}
& \mathrm{S}=\frac{\text { Total Biaya Pemesanan }}{\text { Frekuensi pemesanan }} \\
& =\frac{\text { Rp. } 780.000}{24 \text { kali }} \\
& =\text { Rp. } 32.500 \\
& \text { 3) Tahun } 2019 \\
& \begin{aligned}
S & =\text { Total Biaya Pemesanan } \\
& =\frac{\text { Frekuensi pemesanan }}{24 \text { kali }} \\
& =\text { Rp. } 33.958,33
\end{aligned}
\end{aligned}
$$

b. Biaya penyimpanan per satuan bahan baku $(\mathrm{H})$

1) Tahun 2017

$\mathrm{S}=$ Total Biaya Penyimpanan 
Total Keb. Bahan Baku

$=$ Rp. 15.820 .000

$2.815 \mathrm{~m} 3$

$=$ Rp. $5 \cdot 619,89$ per $\mathrm{m} 3$

2)Tahun 2018

$$
\begin{aligned}
S= & \text { Total Biaya Penyimpanan } \\
= & \frac{\text { Rp. } 17.400 .000}{2.791 \mathrm{~m} 3} \\
& =\text { Rp. } 6.234,32 \text { per } \mathrm{m} 3
\end{aligned}
$$

3)Tahun 2019

$$
\begin{aligned}
S & =\frac{\text { Total Biaya Penyimpanan }}{\text { Total Keb. Bahan Baku }} \\
= & \frac{\text { Rp. } 18 \cdot 215.000}{2.714} \\
& =\text { Rp. } 6.711,49 \text { per } \mathrm{m} 3
\end{aligned}
$$

2. Kebijakan Perusahaan

Perusahaan Perusahaan UD. Jaya

Abadi Putra Kedungpring Lamongan melakukan pemesanan 2 kali dalam satu bulan atau 24 kali dalam waktu satu tahun.

a. Pembelian rata-rata bahan baku (Q) dapat diperhitungkan berdasarkan kebijakan perusahaan sebagai berikut.

- Tahun 2017

$\mathrm{Q}=$ Total keb. bahan baku (D)

Frekuensi

pemesanan

$$
\begin{aligned}
& =\frac{2.815 \mathrm{~m} 3}{24} \\
& =117,29 \mathrm{~m} 3
\end{aligned}
$$

- Tahun 2018

$\mathrm{Q}=$ Total keb. bahan baku

(D)

Frekuensi pemesanan

$$
\begin{aligned}
& =\frac{2.791 \mathrm{~m} 3}{24} \\
& =116,29 \mathrm{~m} 3
\end{aligned}
$$

- Tahun 2019

$$
\begin{aligned}
Q & =\frac{\text { Total keb. bahan baku }(\mathrm{D})}{\text { Frekuensi pemesanan }} \\
& =\frac{2.714 \mathrm{~m} 3}{24} \\
& =113,08 \mathrm{~m} 3
\end{aligned}
$$

Jadi besarnya jumlah pembelian rata-rata bahan baku setiap kali pesan tahun 2017 adalah 117,29 m3 , tahun 2018 adalah 116,29 m3, tahun 2019 adalah 113,08 m3 .

b. Total Biaya Persediaan

- Tahun 2017

Untuk memperhitungkan total biaya persediaan telah diketahui:

Total kebutuhan bahan baku (D) $\quad=2.815 \mathrm{~m} 3$

Pembelian rata-rata bahan baku $(\mathrm{Q})=117,29 \mathrm{~m} 3$

Biaya pemesanan sekali pesan (S) = Rp. 31.250

Biaya penyimpanan per $\mathrm{m} 3$ (H) = Rp. 5.619,89

Perhitungan total biaya persediaan (TIC) sebahgai berikut:

$$
\begin{aligned}
& \left.\left.\mathrm{TIC}=\frac{[\mathrm{D}}{\mathrm{Q}} \times \mathrm{S}\right]+\frac{\mathrm{Q}}{2} \times \mathrm{H}\right] \\
& =\left[\begin{array}{lll}
2.815 & \mathrm{x} & 31.250
\end{array}\right]+[ \\
& 117,29 \times \overline{5.619,89}] \\
& \begin{aligned}
& 117,29 \\
= & \text { Rp. 750.010,66 + Rp. }
\end{aligned}
\end{aligned}
$$

$329.578,45$

$$
=\text { Rp. } 1.079 .589,1
$$

- Tahun 2018

Untuk memperhitungkan total biaya persediaan telah diketahui:

Total kebutuhan bahan baku (D) $=2.791 \mathrm{~m} 3$

Pembelian rata-rata bahan baku $(\mathrm{Q})=116,29 \mathrm{~m} 3$

Biaya pemesanan sekali pesan

(S) = Rp. 32.500

Biaya penyimpanan per $\mathrm{m} 3$ (H) = Rp. 6.234,32

Perhitungan total biaya persediaan (TIC) sebahgai berikut:

$\mathrm{TIC}=\frac{[\mathrm{D}}{\mathrm{Q}} \times \frac{\mathrm{S}]}{2}\left[\begin{array}{c}\mathrm{Q} \times \mathrm{H}] \\ -\end{array}\right.$ 


$$
\begin{aligned}
= & {\left[\begin{array}{lll}
2.791 & \mathrm{x} & 32.500]
\end{array}\right]+[} \\
116,29 & \times 6.234,32] \\
& 116,29 \\
= & \text { Rp. } 780.011,18+\mathrm{Rp} .
\end{aligned}
$$

362.494,54

$$
\text { = Rp. 1.142.505,2 }
$$

- Tahun 2019

Untuk memperhitungkan total biaya persediaan telah diketahui:

Total kebutuhan bahan baku (D) $=2.714 \mathrm{~m} 3$

Pembelian rata-rata bahan baku $(\mathrm{Q})=113,08 \mathrm{~m} 3$

Biaya pemesanan sekali pesan

(S) = Rp. 33.958,33

Biaya penyimpanan per $\mathrm{m} 3$

(H) = Rp. 6.711,49

Perhitungan total biaya persediaan (TIC) sebahgai berikut:

$$
\begin{aligned}
& \left.\mathrm{TIC}=\frac{[\mathrm{D}}{\mathrm{Q}} \times \mathrm{S}\right]+\frac{[\mathrm{Q} \times \mathrm{H}]}{2} \\
& =[2.714 \times 33.958,33]+[ \\
& 113,08 \overline{\times 6.71} 1,49] \\
& 113,08 \\
& 2 \\
& =\text { Rp. 815.023,93 + Rp. } \\
& \text { 379.467,64 } \\
& =\text { Rp. 1.194.491,6 }
\end{aligned}
$$

\section{Metode EOQ}

Langkah-langkah dalam pehitungan dengan menggunakan metode EOQ adalah sebagai berikut:

a. Pembelian bahan baku yang ekonomis

- Tahun 2017

Total kebutuhan bahan baku

(D) $\quad=2.815 \mathrm{~m} 3$

Biaya pemesanan sekali pesan

(S) $\quad=$ Rp. 31.250

Biaya penyimpanan per $\mathrm{m} 3$

(H) $\quad=$ Rp. $5 \cdot 619,89$
Maka besarnya pembelian bahan baku yang ekonomis dapat di perhitungkan dengan metode EOQ sebagai berikut :

$$
\begin{aligned}
Q^{*} & =\frac{\sqrt{2 \mathrm{DS}}}{\sqrt{2 \times 2.815 \times 31.250}} \\
& =\frac{5.619,89}{\sqrt{31.306,21}} \\
& =\sqrt{37,93 \mathrm{~m} 3}
\end{aligned}
$$

- Tahun 2018

Total kebutuhan bahan baku (D) $\quad=2.791 \mathrm{~m} 3$

Biaya pemesanan sekali pesan (S) $\quad=$ Rp. 32.500

Biaya penyimpanan per $\mathrm{m} 3$ (H) = Rp. 6.234,32 Maka besarnya pembelian bahan baku yang ekonomis dapat di perhitungkan dengan metode EOQ sebagai berikut :

$$
\begin{aligned}
\mathrm{Q}^{*} & =\frac{\sqrt{2 \mathrm{DS}}}{} \\
& =\frac{\sqrt{2 \times 2.791 \times 32.500}}{6.234,32} \\
& =\sqrt{2} 29.099,4 \\
& =170,58 \mathrm{~m} 3
\end{aligned}
$$

- Tahun 2019

Total kebutuhan bahan baku (D) $=2.714 \mathrm{~m} 3$

Biaya pemesanan sekali pesan (S) = Rp. 33.958,33

Biaya penyimpanan per $\mathrm{m} 3$ (H) = Rp. 6.711,49

Maka besarnya pembelian bahan baku yang ekonomis dapat di perhitungkan dengan metode EOQ sebágai berikut :

$$
\begin{aligned}
\mathrm{Q}^{*} & =\sqrt{2 \mathrm{DS}} \\
& =\frac{\frac{\mathrm{H}}{\sqrt{2} \times 2.714} \mathrm{x}}{33.958,33 \frac{6.711,49}{}} \\
& =\sqrt{27.464,21} \\
& =165,72 \mathrm{~m} 3
\end{aligned}
$$


Jadi, jumlah pembelian bahan baku yang ekonomis pada tahun 2017 adalah sebesar $176,93 \mathrm{~m} 3$, pada tahun 2018 adalah $170,58 \mathrm{~m} 3$, pada tahun 2019 adalah 165,72 m3 .

b. Frekuensi Pembelian Bahan Baku

Jumlah pemesanan bahan baku yang ekonomis menurut metode EOQ sudah diketahui, maka frekuensi pemesanan (F) menurut metode ini dapat diperhitungkan dengan cara sebagai berikut :

- Tahun 2017

$$
\begin{aligned}
& \mathrm{F}= \mathrm{D} \\
& \mathrm{Q}^{*} \\
&= 2.815 \\
& \Gamma 76,93 \\
&= 15,9 \\
&= 16 \text { kali (dibulatkan) } \\
& \text { - Tahun } 2018 \\
& \mathrm{~F}=\mathrm{D} \\
& \quad \mathrm{Q}^{*} \\
&= 2.791 \\
& 170,58 \\
&= 16,36 \\
&= 16 \text { kali (dibulatkan) }
\end{aligned}
$$

- Tahun 2019

$\mathrm{F}=\mathrm{D}$

$$
Q^{*}
$$$$
=2.714
$$$$
165,37
$$

$$
=16,37
$$

$=16$ kali (dibulatkan)

Jadi frekuensi pemesanan bahan baku pada tahun 2017, 2018 dan 2019 dilakukan sebanyak 16 kali pemesanan dalam kurung waktu 1 tahun.

\section{Total Biaya Persediaan}

- Tahun 2017

Untuk memperhitungkan total biaya persediaan telah diketahui:
Total kebutuhan bahan baku

(D) $\quad=2.815 \mathrm{~m} 3$

Biaya pemesanan sekali pesan

(S) = Rp. 31.250

Biaya penyimpanan per $\mathrm{m} 3$

(H) = Rp. 5.619,89

Pembelian bahan baku yang ekonomis $\left(\mathrm{Q}^{*}\right) \quad=176,93 \mathrm{~m} 3$

Perhitungan total biaya persediaan (TIC) sebahgai berikut:

$$
\begin{aligned}
& \left.\mathrm{TIC}=\left[\frac{\mathrm{D}}{\mathrm{Q}} \times \mathrm{S}\right]+\frac{[\mathrm{Q} \times \mathrm{H}}{2}\right] \\
& =\underline{[2.815} \times \underline{3} \text { 31.250] }+[ \\
& 176,93 \times 5.619,89] \\
& 176,93 \\
& =\text { Rp. } 465 \cdot 443,12+R p . \\
& \text { = Rp. 962.606,69 }
\end{aligned}
$$

- Tahun 2018

Untuk memperhitungkan total biaya persediaan telah diketahui:

Total kebutuhan bahan baku

(D) $\quad=2.791 \mathrm{~m} 3$

Biaya pemesanan sekali pesan

(S) $=$ Rp. 32.500

Biaya penyimpanan per $\mathrm{m} 3$

(H) = Rp. 6.234,32

Pembelian bahan baku yang ekonomis $\left(Q^{*}\right)=170,58 \mathrm{~m} 3$

Perhitungan total biaya persediaan (TIC) sebahgai berikut:

$$
\begin{aligned}
& \left.\left.\mathrm{TIC}=\frac{[\mathrm{D}}{\mathrm{Q}} \times \mathrm{S}\right]+\underset{2}{\mathrm{Q}} \times \mathrm{H}\right] \\
& =\left[\begin{array}{lll}
2.791 & \mathrm{x} & 32.500
\end{array}\right]+[ \\
& 170,58 \times 6.234,32] \\
& 170,58 \\
& 2 \\
& =\text { Rp. } 531 \cdot 759,28+\text { Rp. }
\end{aligned}
$$

$531.725,15$

$$
=\text { Rp. } 1.063 .484,4
$$

- Tahun 2019

Untuk memperhitungkan total biaya persediaan telah diketahui: 
Total kebutuhan bahan baku (D) $\quad=2.714 \mathrm{~m} 3$

Biaya pemesanan sekali pesan (S) = 33.958,33

Biaya penyimpanan per $\mathrm{m} 3$ (H) $=6.711,49$

Pembelian bahan baku yang ekonomis $\left(\mathrm{Q}^{*}\right)=165,72 \mathrm{~m} 3$ Perhitungan total biaya persediaan (TIC) sebahgai berikut:

$\mathrm{TIC}=[\mathrm{D} \times \mathrm{S}]+[\mathrm{Q} \times \mathrm{H}]$

$$
\text { Q } 2
$$

$=[2.714 \times 33.958,33]+[$

$165,72 \times 6.711,49]$

$$
165,72
$$

2

$$
=\text { Rp. 556.136,28 + Rp. }
$$

556.114,06

$$
=\text { Rp. 1.112.250,03 }
$$

a. Penentuan Persediaan Pengaman

Persediaan pengaman atau sering disebut Safety Stock, sangat diperlukan dalam sebuah perushaan karena berfungsi untuk menghindari terjadinya kekurangan bahan baku sehingga memperlancar kegiatan proses produksi. Dalam memperhitungkan persediaan pengaman digunakan metode statistic dengan membandingkan ratarata bahan baku dengan pemakaian bahan baku yang sesungguhnya kemudian dicari penyimpangannya.

1) Perhitungan Standard Deviasi tahun 2017 dapat

\begin{tabular}{|c|c|c|c|c|c|}
\hline \multicolumn{2}{|c|}{ Deviasi } & \multicolumn{3}{|c|}{ Deviasi } & \\
\hline Bulan & $\begin{array}{l}\text { Kebutuhan } \\
\text { Bahan Baku }\end{array}$ & $\bar{X}$ & $\left(\begin{array}{c}x-\bar{x} \\
\text { Bulan }\end{array}\right.$ & $\begin{array}{r}(\mathrm{x}-\overline{\mathrm{K}} \mathrm{b}))_{\text {utuhan }}^{2} \\
\text { Bahan Baku }\end{array}$ & $\mathrm{X}$ \\
\hline Januari & 262 & 234,58 & 27,42 & 751,85 & \\
\hline
\end{tabular}
dilihat pada tabel berikut:

Tabel Perhitungan Standart Deviasi

\begin{tabular}{|c|c|c|c|} 
Februari & 220 & 234,58 & \\
\hline Maet & 242 & 234,58 & \\
\hline April & 202 & 234,58 & \\
\hline Mei & 208 & 234,58 & \\
\hline Juni & 232 & 234,58 & \\
\hline Juli & 235 & 234,58 & \\
\hline Agustus & 242 & 234,58 & \\
\hline September & 228 & 234,58 & \\
\hline Oktober & 238 & 234,58 & \\
\hline November & 245 & 234,58 & \\
\hline Desember & 261 & 234,58 & \\
\hline Total & 2.815 & & \\
\hline
\end{tabular}

Sumber : Data Diolah 2020

$$
\begin{aligned}
\bar{X} & =\frac{D}{n} \\
& =\frac{2.815}{12 \text { Bulan }} \\
& =234,58 \\
\mathrm{SD} & =\frac{\sqrt{\sum(X-\bar{X})^{2}}}{\mathrm{n}} \\
& =\frac{\sqrt{3710,84}}{12} \\
& =\sqrt{309,23} \\
& =17,58 \mathrm{~m} 3
\end{aligned}
$$

Berdasarkan penelitian-

penelitian terdahulu, bahwa dengan asumsi manajemen perusahaan memilih standard penyimpangan $5 \%$ sehingga diperoleh $\mathrm{Z}$ dengan tabel standard deviasi sebesar 1,65.

$$
\begin{aligned}
\text { Safety Stock } & =\text { SD } \times \text { Z } \\
& =17,58 \times 1,65 \\
& =29 \mathrm{~m} 3
\end{aligned}
$$

1) Perhitungan Standard Deviasi tahun 2018 dapat dilihat pada tabel berikut :

Tabel Perhitungan Standart 


\begin{tabular}{|c|c|c|c|c|c|}
\hline Januari & 255 & 232,58 & Feb5\&ari & 2387,45 & 226,16 \\
\hline Februari & 230 & 232,58 & $-\mathrm{M} / 8 \mathrm{t}$ & 2316,65 & 226,16 \\
\hline Maet & 238 & 232,58 & \$APil & 2139,37 & 226,16 \\
\hline April & 218 & 232,58 & 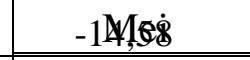 & 22012,57 & 226,16 \\
\hline Mei & 222 & 232,58 & -15uெ & 20811,93 & 226,16 \\
\hline Juni & 226 & 232,58 & $-6, \mathfrak{g l d}$ & $22 \$ 3,29$ & 226,16 \\
\hline Juli & 199 & 232,58 & Aggussus & $2 B .327,61$ & 226,16 \\
\hline Agustus & 244 & 232,58 & Septenper & 224530,41 & 226,16 \\
\hline September & 238 & 232,58 & Okt4ober & 2149,37 & 226,16 \\
\hline Oktober & 240 & 232,58 & NoN, $₫$ Diber & 2185,05 & 226,16 \\
\hline November & 222 & 232,58 & Dqæessber & 241311,93 & 226,16 \\
\hline Desember & 259 & 232,58 & $26,4+a 1$ & 276198,01 & \\
\hline Total & 2.791 & & Sumber : Data & Diq.oht, 20420 & \\
\hline
\end{tabular}

Sumber : Data Diolah 2020

$$
\begin{aligned}
\bar{X}= & \frac{D}{N} \\
= & \frac{2.791}{12 \text { Bulan }} \\
= & 232,58 \\
\mathrm{SD} & =\frac{\sqrt{\sum(\mathrm{X}-\overline{\mathrm{X}})^{2}}}{\mathrm{n}} \\
& =\sqrt{\frac{12.613,64}{\sqrt{217,80}}} \\
& =\sqrt{\sqrt{217}} \\
& =14,75 \mathrm{~m} 3
\end{aligned}
$$

Berdasarkan penelitianpenelitian terdahulu, bahwa dengan asumsi manajemen perusahaan memilih standard penyimpangan 5\% sehingga diperoleh $\mathrm{Z}$ dengan tabel standard deviasi sebesar 1,65.

Safety Stock $=$ SD x Z

$$
\begin{aligned}
& =14,75 \times 1,65 \\
& =24,33 \mathrm{~m} 3
\end{aligned}
$$

3) Perhitungan Standard Deviasi tahun 2019 dapat dilihat pada tabel berikut:

Tabel Perhitungan Standart Deviasi

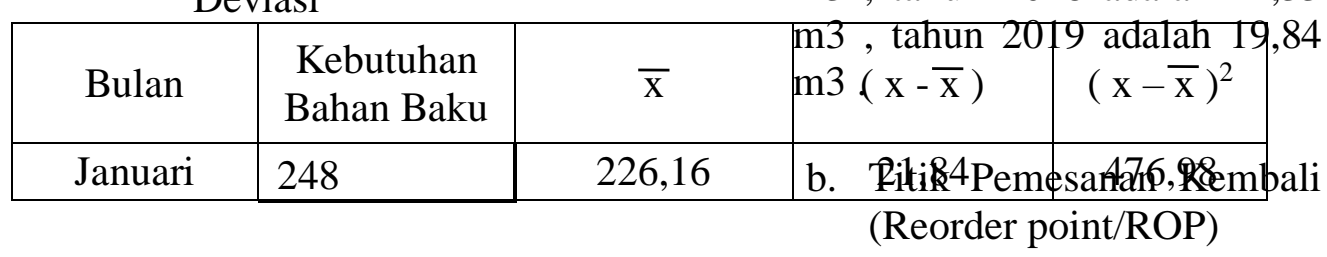

$$
\begin{aligned}
\bar{X}= & \frac{D}{n} \\
= & \frac{2.714}{12 \text { Bulan }} \\
= & 226,16 \\
\text { SD } & =\sqrt{\sum(X-\bar{X})^{2}} \\
= & \frac{\sqrt{1.737,6}}{12} \\
= & \sqrt{144,8} \\
= & 12,03 \mathrm{~m} 3
\end{aligned}
$$

Berdasarkan penelitianpenelitian terdahulu, bahwa dengan asumsi manajemen perusahaan memilih standard penyimpangan $5 \%$ sehingga diperoleh $\mathrm{Z}$ dengan tabel standard deviasi sebesar 1,65.

$$
\begin{aligned}
\text { Safety Stock } & =\text { SD } \times \text { Z } \\
& =12,03 \times 1,65 \\
& =19,84 \mathrm{~m} 3
\end{aligned}
$$

Jadi, persediaan bahan baku yang harus disediakan perusahaan sebagai persediaan pengaman tahun 2017 adalah 29 m3, tahun 2018 adalah 24,33 (Reorder point/ROP) 
Waktu tunggu atau Lead Time yang diperlukan oleh perusahaan dalam menunggu datangnya bahan baku yang dipesan rata-rata adalah 3 hari, dengan rata-rata jumlah hari kerja (t) 300 hari dalam setahun. Sebelum menghitung besarnya ROP maka terlebih dahulu dicari tingkat penggunaan bahan baku per hari dengan cara sebagai berikut :

- Tahun 2017

$$
\begin{aligned}
\mathrm{d}= & \mathrm{D} \\
& \mathrm{t} \\
= & 2.815 \\
& 300 \\
& =9,38
\end{aligned}
$$

Maka titik pemesanan kembali (ROP) adalah SS

$$
\text { ROP }=(\text { Lead time } \mathrm{x} \mathrm{d})+
$$

$$
\begin{aligned}
& =(3 \times 9,38)+29 \\
& =57,14 \mathrm{~m} 3
\end{aligned}
$$

- Tahun 2018

$$
\begin{aligned}
d & =\frac{D}{t} \\
& =\frac{2.791}{300} \\
& =9,3
\end{aligned}
$$

Maka titik pemesanan kembali (ROP) adalah

$$
\begin{aligned}
\mathrm{ROP} & =(\text { Lead time } \mathrm{x} \mathrm{d}) \\
& =(3 \times 9,3)+24,33 \\
& =52,23 \mathrm{~m} 3
\end{aligned}
$$

- Tahun 2019

$$
\begin{gathered}
\mathrm{d}=\frac{\mathrm{D}}{\mathrm{t}} \\
=\frac{2.714}{300} \\
=9,04
\end{gathered}
$$

Maka titik pemesanan kembali (ROP) adalah

$$
\begin{aligned}
& \text { ROP }=(\text { Lead time } \mathrm{x} \mathrm{d}) \\
& +\mathrm{SS} \\
& 19,84 \\
& =\left(\begin{array}{lll}
3 & \mathrm{x} & 9,04
\end{array}\right)+ \\
& =46,96 \mathrm{~m} 3
\end{aligned}
$$

4. Perbandingan

Hasil perhitungan dengan menggunakan kebijakan perusahaan dan dengan menggunakan metode EOQ telah diketahui, maka perbandingan dapat dilakukan untuk memperoleh hasil yang paling efisien.sebagai berikut ;

\section{a. Tahun 2017}

Tabel Perbandingan Kebijakan

Perusahaan Dengan

Metode EOQ Tahun 2017

\begin{tabular}{|c|l|r|}
\hline \multirow{2}{*}{ No } & \multicolumn{1}{|c|}{ Keterangan } & T \\
\cline { 3 - 3 } & $\begin{array}{l}\text { Pembelian rata-rata } \\
\text { bahan baku }\end{array}$ & 117,29 \\
\hline 2 & Total biaya persediaan & Rp. 1.079.58 \\
\hline 3 & Frekuensi pemesanan & 24 kali \\
\hline 4 & Safety stock & - \\
\hline 5 & Reorder point & - \\
\hline
\end{tabular}

b. Tahun 2018

Tabel Perbandingan Kebijakan Perusahaan Dengan Metode EOQ

Tahun 2018

\begin{tabular}{|c|l|r|}
\hline No & \multicolumn{1}{|c|}{ Keterangan } & Kebijakan Perus \\
\cline { 3 - 3 } & & $\begin{array}{l}\text { Pembelian rata-rata } \\
\text { bahan baku }\end{array}$ \\
\hline 2 & Total biaya persediaan & Rp. 1.142.5 \\
\hline 3 & Frekuensi pemesanan & 24 kali \\
\hline 4 & Safety stock & - \\
\hline
\end{tabular}


$5 \quad$ Reorder point

c. Tahun 2019

Tabel Perbandingan Kebijakan

Perusahaan Dengan Metode EOQ

Tahun 2019

\begin{tabular}{|c|l|r|}
\hline No & \multicolumn{1}{|c|}{ Keterangan } & $\begin{array}{l}\text { Kebijak } \\
\text { Peruadha }\end{array}$ \\
\hline 1 & $\begin{array}{l}\text { Pembelian rata-rata } \\
\text { bahan baku }\end{array}$ & 11 \\
\hline 2 & Total biaya persediaan & Rp. 1 \\
\hline 3 & Frekuensi pemesanan & \\
\hline 4 & Safety stock & \\
\hline 5 & Reorder point & \\
\hline
\end{tabular}

\section{Pembahasan}

1) Tahun 2017 Pembelian rata-rata bahan baku dengan Metode EOQ lebih efisien dengan jumlah 176,93 dengan 16 kali pemesanan dalam waktu satu tahun dan hanya menghabiskan biaya persediaan sebesar Rp. 962.606,69 Jika dibandingkan dengan kebijakan perusahaan yang melakukan pemesanan sebanyak 24 kali dalam setahun dengan jumlah 117,29 m3 yang mengeluarkan biaya persediaan sampai Rp 1.079.589,1. Maka dengan menggunakan Metode EOQ, perusahaan dapat menghemat biaya persediaan Rp 116.982,41. Perusahaan Perusahaan UD. Jaya Abadi Putra Kedungpring Lamongan tidak menetapkan adanya persediaan pengaman dalam kebijakannya, sedangkan dalam Metode EOQ, perusahaan harus mengadakan persediaan pengaman untuk memperlancar proses produksi dalam jumlah sebesar $29 \mathrm{~m} 3$ Adanya Titik Pemesanan Kembălì (ROP) dalam Metode EOQ untuk mengantisipasi keterlambatan pengiriman bahan baku. Menurut metode EOQ, perusahaan harus melakukan pemesanan bahan baku kembali saat persediadnubaloar baku berada pada

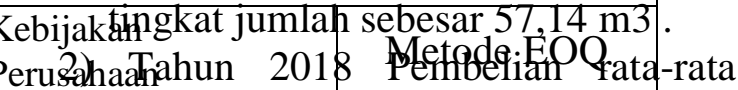
bahan baku dengan Metode EOQ 1 Pebin mefisien dengan, jumpăh 170,58 dengan 16 kali pemesanan dalam

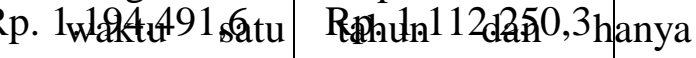
menghabiskan biaya persediaan 34hedàr Rp. 1.063k4\$4,4. Jika dibandingkan dengan kebijakan perusahaan yang,84 migelakukan pemesanan sebanyak 24 kali dalam setahun dengan jump, $\mathrm{m} 36,29 \mathrm{~m} 3$ yang mengeluarkan biaya persediaan sampai Rp 1.142.505,2. Maka dengan menggunakan Metode EOQ, perusahaan dapat menghemat biaya persediaan Rp 79.020,8. Perusahaan Perusahaan UD. Jaya Abadi Putra Kedungpring Lamongan tidak menetapkan adanya persediaan pengaman dalam kebijakannya, sedangkan dalam Metode EOQ, perusahaan harus mengadakan persediaan pengaman untuk memperlancar proses produksi dalam jumlah sebesar 24,33 m3 . Adanya Titik Pemesanan Kembali (ROP) dalam Metode EOQ untuk mengantisipasi keterlambatan pengiriman bahan baku. Menurut metode EOQ, perusahaan harus melakukan pemesanan bahan baku kembali saat persediaan bahan baku berada pada tingkat jumlah sebesar $52,23 \mathrm{~m} 3$.

3) Tahun 2019 Pembelian rata-rata bahan baku dengan Metode EOQ lebih efisien dengan jumlah 165,72 dengan 16 kali pemesanan dalam waktu satu tahun dan hanya 
menghabiskan biaya persediaan sebesar Rp. 1.112.250,3. Jika dibandingkan dengan kebijakan perusahaan yang melakukan pemesanan sebanyak 24 kali dalam setahun dengan jumlah 113,08 m3 yang mengeluarkan biaya persediaan sampai Rp 1.194.491,6. Maka dengan menggunakan Metode EOQ, perusahaan dapat menghemat biaya persediaan $\mathrm{Rp}$ 82.241,3. Perusahaan Perusahaan UD. Jaya Abadi Putra Kedungpring Lamongan tidak menetapkan adanya persediaan pengaman dalam kebijakannya, sedangkan dalam Metode EOQ, perusahaan harus mengadakan persediaan pengaman untuk memperlancar proses produksi dalam jumlah sebesar 19,84 m3 . Adanya Titik Pemesanan Kembali (ROP) dalam Metode EOQ untuk mengantisipasi keterlambatan pengiriman bahan baku. Menurut metode EOQ, perusahaan harus melakukan pemesanan bahan baku kembali saat persediaan bahan baku berada pada tingkat jumlah sebesar 46,96 .

4).Berdasarkan hasil penelitian terjadi efektiitas produksi optimum pada perusahaan terjadi pada tahun 2017 karena dengan Metode EOQ perusahaan dapat menghemat biaya persediaan Rp 116.982,41. Penelitian ini mendukung penelitian Muh. Taufik Malik (2013, Fahmi Ramadhan (2014) dan Syifaur Rohmaz (2016) yang menyatakan bahwa jika perusahaan jika perusahaan menggunakan metode EOQ menalami efektifitas baik pembelian bahan baku dan penyimpanan barang.

\section{SIMPULAN DAN SARAN Simpulan}

Berdasarkan hasil penelitian dan analisis data pada bab-bab sebelumnya dapat dikemukakan simpulan sebagai berikut :

1. Jumlah pembelian persediaan bahan baku Tepung Beras ketan yang efisien dengan menggunakan metode EOQ pada tahun 2017 adalah sebesar $176,93 \mathrm{~m} 3$ dengan frekuensi pemesanan 16 kali, pada tahun 2018 adalah sebesar 170,58 m3 dengan frekuensi pemesanan 16 kali, pada tahun 2019 adalah sebesar 165,72 m3 dengan frekuensi pemesanan 16 kali. Dan total biaya persediaan bahan baku perusahaan dalam perhitungan EOQ pada tahun 2017 sebesar Rp. 962.606, pada tahun 2018 sebesar Rp. 1.063.484,4, pada tahun 2019 sebesar Rp. 1.112.250,3. Persediaan pengaman (Safety Stock) menurut perhitungan EOQ pada tahun 2017 adalah $29 \mathrm{~m} 3$, tahun 2018 adalah 24,33 m3 , tahun 2019 adalah 19,84. Titik pemesanan kembali (Reorder Point) menurut perhitungan EOQ pada tahun 2017 sebesar 57,14 m3, tahun 2018 sebesar 52,23 m3 ,pada tahun 2019 sebesar 46,96 m3 .

2. Kebijakan Persediaan bahan baku yang dilakukan oleh UD Jaya Abadi Putra Kedungpring Lamongan selama ini masih belum efisien bila dibandingkan dengan penerapan persediaan bahan baku dengan menggunakan metode EOQ.

\section{Saran}

Berdasarkan perhitungan penelitian, maka saran yang dapat dijadikan sebagai bahan pertimbangan dalam kebijakan pengadaan bahan baku di UD Jaya Abadi Putra Kedungpring Lamongan sebagai berikut :

1. Hendaknya perusahaan mempertimbangkan penggunaan Metode EOQ dalam kebijakan pengadaan bahan baku. Karena 
dengan menggunakan metode EOQ perusahaan akan mendapatkan kuantitas pembelian bahan baku yang optimal dan efisien dengan biaya yang minimum dibandingkan kebijakan perusahaan sebelumnya.

2. Perusahaan sebaiknya menentukan besarnya Safety Stock dan Reorder Point dalam pengendalian persediaan untuk melindungi atau menjaga kemungkinan kekurangan bahan baku karena pemakaian bahan baku yang lebih besar dari perkiraan serta menjaga kemungkinan keterlambatan bahan baku yang dipesan.

3. Gudang perlu diperluas agar fungsi gudang dapat dioptimalkan sebagai tempat penyimpanan maupun arus keluar masuk bahan baku.

\section{DAFTAR PUSTAKA}

Affif Subakhtiar 2016. Analisis Pengendalian Persediaan Bahan Baku AKU Dengan Metode EOQ (Economic Order Quantity) di Jaya Tehknik Aluminium Kecamatan Turi Lamongan. FE Universitas Islam Lamongan (UNISLA).

Fahmi Ramadhan (2014). Analisis persediaan Bahn baku dengan menggunakan metode EOQ (Economic Order Quantity) Sulawesi.
Gejdos, Pavel. (2015), Continuous Quality Improvement by Statistical Process Control, Business Economics and Management 2015 Conference, aTechnical University in Zvolen, Masarykova 24, 960 53, Zvolen, Slovakia.

Heizer, Jay. dan Render, Barry. (2015), Manajemen Operasi, Edisi kesebelas, Salemba Empat, Jakarta.

Muh. Taufik Malik (2013). Analisis Persediaan Bahan Baku Kertas Menggunakan Metode EOQ (Economic Order Quantity) Pada Harian Tribun Timur Makassar

Sutarti, Sutriyono, Dhayal Gustopo 2016. Analisis Pengendalian Persediaan Bahan Baku Menggunakan Metode Economic Order Quantity Dalam Upaya Meningkatkan Efisiensi. Jurnal Teknologi dan Manajemen Industri, Vol. 2 No. 2.

Syifaur Rohmah 2016. Analisis Pengendalian Persediaan Bahan Baku menunjang Efektifitas Proses Produksi Roti Kiky Bakery Kemantren Paciran Lamongan. FE Universitas Islam Lamongan (UNISLA).

Sugiyono (2017), Metode Penelitian, Cetakan kedupuluhenam, Alfabeta, Bandung 